\title{
CALCIUM/CALMODULIN-DEPENDENT PROTEIN PHOSPHORYLATION IN THE NERVOUS SYSTEM OF APLYSIA
}

\author{
SUSAN A. DERIEMER, ${ }^{2}$ LEONARD K. KACZMAREK, YVONNE LAI, ${ }^{3}$ TERESA L. McGUINNESS, ${ }^{3}$ \\ AND PAUL GREENGARD ${ }^{3}$
}

Departmenl of Pharmacology, Yale Universily School of Medicine, New Haven, Connecticul 06510

Received October 28, 1983; Revised January 24, 1984; Accepted January 30, 1984

\begin{abstract}
An afterdischarge in the bag cell neurons of Aplysia was previously shown to be associated with calcium entry into these cells and with changes in the phosphorylation state of at least two bag cell proteins (BC-I and BC-II). We have now investigated the role of calcium plus calmodulin (Ca/ $\mathrm{CaM}$ ) in the control of phosphorylation of Aplysia nervous system proteins, including those of the bag cell neurons.

In cell-free preparations of Aplysia $\mathrm{CNS}$, we demonstrated $\mathrm{Ca} / \mathrm{CaM}$-stimulated protein phosphorylation that could be inhibited by the calmodulin-blocking drugs R24571, trifluoperazine, chlorpromazine, and W7. A number of substrate proteins for $\mathrm{Ca} / \mathrm{CaM}$-dependent protein phosphorylation with $M_{\mathrm{r}}$ values from 17,000 to 310,000 were consistently observed in homogenates of the Aplysia CNS. In the bag cells, we found that a major substrate for $\mathrm{Ca} / \mathrm{CaM}$-dependent protein phosphorylation was the bag cell-specific, $M_{\mathrm{r}}=21,000$ protein $(\mathrm{BC}-\mathrm{II})$. BC-I $\left(M_{\mathrm{r}}=33,000\right)$, on the other hand, appeared not to be a substrate for a $\mathrm{Ca} / \mathrm{CaM}$-dependent protein kinase.

We found that there are a minimum of two $\mathrm{Ca} / \mathrm{CaM}$-dependent protein kinases in the Aplysia nervous system. These enzymes were distinguished on the basis of their subcellular distribution and their ability to phosphorylate distinct sites on synapsin I, an exogenous neuronal protein from vertebrates. Phosphorylation by one of these kinases (calmodulin kinase I) was on a site recovered in an $M_{\mathrm{r}}=10,000$ proteolytic fragment of synapsin I, and phosphorylation by the other (calmodulin kinase II) was on a site recovered in an $M_{\mathrm{r}}=30,000$ fragment. The predominant enzyme in the Aplysia CNS, as in the mammalian nervous system, was calmodulin kinase II.

In addition, we compared an $M_{\mathrm{r}}=51,000$ Aplysia substrate for $\mathrm{Ca} / \mathrm{CaM}$-dependent phosphorylation with the $M_{\mathrm{r}}=50,000$ to 51,000 subunit of mammalian calmodulin kinase II. Both proteins showed immunoreactivity with monoclonal antibodies raised against rat calmodulin kinase II, both bound calmodulin, and phosphorylation of both proteins followed by partial proteolysis with Staphylococcus aureus protease V8 led to similar phosphopeptide maps.

Our results indicate that the major form of $\mathrm{Ca} / \mathrm{CaM}$-dependent protein kinase in Aplysia $\mathrm{CNS}$ is homologous to mammalian calmodulin kinase II. 'The findings also raise the possibility that calcium/ calmodulin-dependent phosphorylation may mediate some of the long-lasting effects of intracellular calcium entry during an afterdischarge of the bag cell neurons.
\end{abstract}

Calcium plays a dual role within nerve cells. It carries electrical current through voltage-gated channels in the membrane, and it also acts as a second messenger within

\footnotetext{
' This work was supported by National Science Foundation Grant BWS-8202364 to L. K. K. and by United States Public Health Service Grants NS-18492 to L. K. K. and MH-17387 and NS-08440 to P. G.; a contract from the United States Air Force Schuol of Aerospace Medicine; Training Grants CA-09085 to S. A. D., GM-07324 to Y. L., and GM-07205 to T. L. M.; and a National Science Foundation predoctoral fellowship to S. A. D.

${ }^{2}$ To whom correspondence should be addressed.

${ }^{3}$ Present address: The Rockefeller University, 1230 York Avenue, New York, NY 10021.
}

the cell by activating a wide range of intracellular enzymes. Among the enzymes which are regulated by intracellular calcium ions in nerve cells are calcium/calmodulin-dependent protein kinases (Ca/CaM-PKs). Although no definite function has yet been established for any of the several $\mathrm{Ca} / \mathrm{CaM}-\mathrm{PK}$ s which are present in the vertebrate brain, a role in synaptic transmission has been proposed on the basis of their enrichment in neurons, the association of their substrates with synaptic vesicles and postsynaptic densities, and the inhibition of neurotransmitter release by calmodulin-blocking drugs (Schulman and Greengard, 1978; DeLorenzo et al., 1979; Grab et al., 1981; Kennedy et al., 1983a; Palfrey et al., 1983; Kelly et al., 1984). One way to test this hypothesis would 
be to alter the activity of these enzymes or their substrates in one cell while recording the electrical responses of that cell and those of follower cells. Because of the difficulty in performing such experiments within the vertebrate central nervous system, we have begun to study calcium/calmodulin-dependent protein phosphorylation in the nervous system of the marine mollusc, Aplysia.

The advantages of using invertebrates, such as Aplysia, with their large, identifiable neurons for studies which combine biochemical and electrophysiological manipulations are evident from recent work showing the modulation of membrane channels by cAMP-dependent protein kinase (cAMP-PK) (Castellucci et al., 1980; Kaczmarek et al., 1980; Adams and Levitan, 1982; Alkon et al., 1983). In addition, calcium entry has been demonstrated to produce long-lasting changes in the activity of invertebrate nerve cells (Acosta-Urquidi et al., 1982; Kandel and Schwartz, 1982; Kaczmarek and Kauer, 1983), and such prolonged modifications of electrical properties may involve $\mathrm{Ca} / \mathrm{CaM}$-dependent protein phosphorylation (Acosta-Urquidi et al., 1982).

In the present study, we had three main goals: (1) to identify drugs which can be used to alter $\mathrm{Ca} / \mathrm{CaM}$-dependent phosphorylation in Aplysia; (2) to identify Aplysia proteins that are substrates for $\mathrm{Ca} / \mathrm{CaM}-\mathrm{PKs}$ and that may, therefore, be involved in calcium-dependent modulation of neuronal activity; (3) to compare $\mathrm{Ca} /$ CaM-dependent phosphorylation in the mammalian brain with that in the Aplysia nervous system.

Within the Aplysia nervous system, we have focused attention on the bag cell neurons which, in response to brief stimulation, generate a 30-min afterdischarge. There are several well characterized physiological effects of calcium that one can study in these cells, including peptide secretion, a calcium-dependent phase of the afterdischarge, and a period of electrical refractoriness (16 to $20 \mathrm{hr}$ ) that is induced by calcium entry during the afterdischarge (Stuart et al., 1980; Kaczmarek et al., 1982; Kaczmarek and Kauer, 1983). It is likely that one or more of these processes involves $\mathrm{Ca} / \mathrm{CaM}$-dependent protein phosphorylation.

The $\mathrm{Ca} / \mathrm{CaM}-\mathrm{PKs}$ in vertebrate brain have been distinguished, in part, on the basis of their preference for specific substrate proteins. Using this criterion, we have been able to identify two enzymes in the Aplysia CNS as homologues of vertebrate calmodulin kinases which phosphorylate the neuron-specific mammalian protein, synapsin I. In addition, we have carried out a detailed comparison of the major Aplysia and vertebrate synapsin I calmodulin kinases.

A preliminary report of this work has been published (DeRiemer et al., 1982).

\section{Materials and Methods}

Aplysia californica, obtained from Alacrity Marine Biological Services (Newport Beach, CA), were maintained in artificial sea water (Instant Ocean) at $14^{\circ} \mathrm{C}$. Animals were sacrificed, the central nervous system ganglia were removed, and as much connective tissue as possible was dissected away. CNS ganglia preparations used in these experiments consisted of pooled pleural, pedal, buccal, and cerebral ganglia. In some experiments isolated bag cell clusters were used. The tissue was homogenized on ice in 0.2 to $1.0 \mathrm{ml}$ of homogenization buffer $(50 \mathrm{mM}$ Tris, $5 \mathrm{~mm}$ EDTA, $1 \mathrm{~mm}$ EGTA, $5 \mathrm{~mm}$ 2-mercaptoethanol, $0.1 \mathrm{~mm}$ phenylmethylsulfonyl fluoride, $\mathrm{pH} 7.2$ ) using a ground glass tissue grinder. Excess connective tissue was removed by centrifugation at $1000 \times g$ for 1 min. Protein was determined by the method of Lowry et al. (1951).

Particulate and cytosolic fractions were prepared by centrifugation of homogenates at $100,000 \times g$ for $1 \mathrm{hr}$ in a Beckman ultracentrifuge. Particulate pellets were resuspended in the original volume of homogenization buffer.

Homogenates were subjected to ammonium sulfate fractionation to remove endogenous calmodulin, using the method of Yamauchi and Fujisawa (1979). Ammonium sulfate was added to samples to $55 \%$ saturation. Samples were stirred on ice for 30 to $45 \mathrm{~min}$, followed by centrifugation at $28,000 \times g$ for $20 \mathrm{~min}$. Pellets were resuspended in the original volume of homogenization buffer and dialyzed for 4 to $8 \mathrm{hr}$ at $4^{\circ} \mathrm{C}$.

Standard phosphorylation assays were carried out in a final volume of $100 \mu \mathrm{l}$ containing $50 \mu \mathrm{l}$ of homogenate ( 0.2 to $1.0 \mathrm{mg} / \mathrm{ml}$ of protein), $10 \mathrm{mM} \mathrm{MgCl}_{2}$, and appropriate additions. For calcium-free solutions, EGTA was added to a final concentration of $1.5 \mathrm{mM}$. Where indicated, calcium and calmodulin were added to final con centrations of $1.0 \mathrm{mM}$ (approximately $0.5 \mathrm{~mm}$ free) and $10 \mu \mathrm{g} / \mathrm{ml}$, respectively. Reaction mixtures were pre-incubated for $1 \mathrm{~min}$ at $20^{\circ} \mathrm{C}$, and reactions were initiated by addition of $\left[\gamma^{32} \mathrm{P}\right]$ ATP $(50 \mu \mathrm{M})$. Reactions were stopped after $2 \mathrm{~min}$ by addition of $50 \mu$ l of "Stop" solution $(20 \% \mathrm{v} / \mathrm{v}$ glycerol, $10 \% \mathrm{v} / \mathrm{v} 2$-mercaptoethanol, $9 \% \mathrm{w} / \mathrm{v}$ SDS, $125 \mathrm{~mm}$ Tris, $\mathrm{pH}$ 6.8, $3 \mathrm{~mm}$ EDTA, and a trace of bromphenol blue) followed by boiling for $2 \mathrm{~min}$. Samples were subjected to SDS-PAGE using the system of Laemmli (1970). Gels were stained for protein with Coomassie brilliant blue, destained, dried, and autoradiographed using Kodak X-Omat film and Dupont Lightning plus intensifying screens. Phosphate incorporation into specific protein bands was quantitated by cutting the bands from the dried gel, followed by liquid scintillation counting.

Binding of $\left[{ }^{125} \mathrm{I}\right]$ calmodulin to proteins separated by SDS-PAGE was carried out according to the method of Carlin et al. (1981). The transfer of proteins from SDSpolyacrylamide gels to nitrocellulose and detection of antigens by immunoblotting with the mouse monoclonal antibody (C42.1) were carried out by a modification of the method of Towbin et al. (1979) as previously described (Kelly et al., 1984). One-dimensional proteolysis maps were prepared by the method of Cleveland et al. (1977) using $10 \mu \mathrm{g}$ of Staphylococcus aureus V8 protease per sample; samples were digested in a $3.5-\mathrm{cm}$ stacking gel during electrophoresis at $60 \mathrm{~V}$ followed by separation on a $15 \%$ SDS-polyacrylamide gel.

Calmodulin was purified from bovine brain by the procedure of Grand et al. (1979). Synapsin I was prepared by a modification of the method of Ueda and Greengard (1977). Calmodulin kinase II was purified from rat brain by the method of Kennedy et al. (1983b) as modified by McGuinness et al. (1984). $\left[{ }^{32} \mathrm{P}\right]$ ATP was prepared by the method of Glynn and Chappell (1964) with ATP (Sigma) 
and carrier-free $\left[{ }^{32} \mathrm{P}\right.$ ] orthophosphate (New England Nuclear) to a specific activity of 5 to $10 \times 10^{7} \mathrm{cpm} / \mathrm{nmol}$.

R24571 (1-[bis ( $p$-chlorophenyl)methyl]-3-[2,4-dichloro-B-(2,4-dichlorobenzyloxy)phenethyl]imidizolium chloride) was obtained from Janssen Pharmaceuticals (Beerse, Belgium). Trifluoperazine and chlorpromazine were obtained from Smith, Kline and French. W7 $(N-$ (6-aminohexyl)-5-chloro-1-napthalenesulfonamide hydrochloride) was obtained from Rikaken Co., Ltd. (Nagoya, Japan). Catalytic subunit of cAMP-PK from bovine heart and myosin light chains from rabbit skeletal muscle were gifts of Dr. A. Nairn. Iodinated calmodulin was a gift of Drs. F. Gorelick and J. Jamieson. The preparation of tubulin, containing microtubule-associated proteins, was a gift of Dr. J. Rosenbaum. Smooth muscle myosin light chains from turkey gizzard were a gift of Dr. R. S. Adelstein. Goat anti-mouse $\operatorname{IgG}\left(\mathrm{Fab}^{\prime}\right)^{2}$ fragment conjugated to alkaline phosphatase was obtained from Boehringer Mannheim. Phosphorylase $b$, histone F3, casein, phosvitin, 8-Br-cAMP, and isobutyl methylxanthine (IBMX) were obtained from Sigma. $S$. aureus V8 protease was obtained from Miles Biochemicals.

Molecular weight markers used were the subunits of RNA polymerase $(165,000,155,000$, and 90,000$)$, phosphorylase $b(97,400)$, bovine serum albumin $(68,000)$, ovalbumin $(45,000)$, carbonic anhydrase $(31,000)$, chymotrypsinogen A $(25,000)$, myoglobin $(17,000)$, and hemoglobin $(16,000)$.

\section{Results and Discussion}

Calcium/calmodulin-dependent protein phosphorylation. Addition of calcium to homogenates of the Aplysia nervous system led to a large increase in the incorporation of ${ }^{32} \mathrm{P}$ from $\left[\gamma-{ }^{32} \mathrm{P}\right] \mathrm{ATP}$ into certain phosphoproteins (Fig. $1 A$ ). In crude homogenates, this effect was only slightly enhanced by the addition of exogenous calmodulin. In preparations from which endogenous calmodulin had been removed by ammonium sulfate fractionation, the effect of calcium alone was reduced, and a stimulation of phosphate incorporation was seen when calmodulin was added back to the reaction mixture (Fig. $1 B)$.

To examine the sensitivity of the $\mathrm{Ca} / \mathrm{CaM}-\mathrm{PK}$ in Aplysia to drugs that inhibit calmodulin-dependent processes in other systems, we measured phosphate incorporation into an $M_{\mathrm{r}}=51,000$ Aplysia protein which was a major endogenous substrate for calcium-dependent protein kinase activity (Fig. 1). We tested four drugs: R24571, trifluoperazine, chlorpromazine, and W7. Each drug inhibited phosphorylation of the $M_{\mathrm{r}}=51,000$ protein (Fig. 2) at a dose consistent with its efficacy as a calmodulin antagonist (Hidaka et al., 1978; Weiss et al., 1980; Van Belle, 1981).

Endogenous substrates for Ca/CaM-PK in Aplysia. In homogenates of the Aplysia nervous system and in isolated bag cell clusters, calcium plus calmodulin stimulated the phosphorylation of a number of endogenous phosphoproteins $\left(M_{\mathrm{r}}\right.$ values $\left(\times 10^{-3}\right)$ were: $310,205,161$, $112,104,93,75,61,51,36,30,25$, and 17). A subset of these $\left(M_{\mathrm{r}}\right.$ values $\left(\times 10^{-3}\right)=161,112,93,75,25$, and 17$)$ were also substrates for cAMP-PK (Fig. 3). The most prominent of the group of proteins which appeared to be
A.

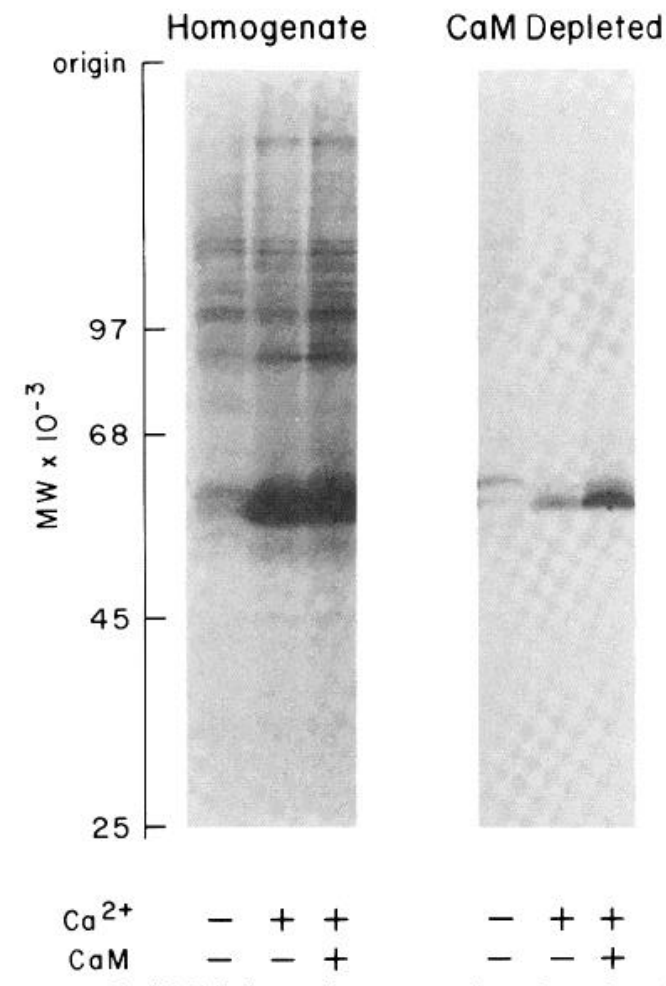

Figure 1. $\mathrm{Ca} / \mathrm{CaM}$-dependent protein phosphorylation in cell-free preparation of Aplysia CNS ganglia. Protein phosphorylation was carried out in the absence $(-)$ or presence $(+)$ of calcium or calcium plus calmodulin as indicated, either before $(A)$ or after $(B)$ removal of endogenous calmodulin by ammonium sulfate fractionation. Radioactive proteins were then subjected to SDS-PAGE and autoradiography.

substrates only for Ca/CaM-PK was the $M_{\mathrm{r}}=51,000$ phosphoprotein.

Our data on the presence of $\mathrm{Ca} / \mathrm{CaM}-\mathrm{PK}$ activity in cell-free preparations of the Aplysia CNS, the inhibition by calmodulin antagonists, and the pattern of endogenous substrates for $\mathrm{Ca} / \mathrm{CaM}-\mathrm{PK}$ and cAMP-PK were, in general, similar to those of Novak-Hofer and Levitan (1983), although we used different classes of calmodulinblocking drugs and a different technique for removing endogenous calmodulin.

We compared the proteins in bag cells that were phosphorylated by endogenous $\mathrm{Ca} / \mathrm{CaM}-\mathrm{PK}$ activity with those proteins whose phosphorylation state changes in association with bag cell afterdischarge. This prolonged period of intense electrical activity, which can be triggered by a brief electrical stimulus, is accompanied by enhanced phosphorylation of at least two proteins, BC-I $\left(M_{\mathrm{r}}=33,000\right)$ and BC-II $\left(M_{\mathrm{r}}=21,000\right)$. BC-II appears to be specific to, or enriched in, bag cells, and both proteins are substrates for cAMP-PK (Jennings et al., 1982). One of the major substrates for $\mathrm{Ca} / \mathrm{CaM}$-dependent protein phosphorylation in the bag cells appeared, on the basis of its migration, to be BC-II (Fig. 3). BC-I was not a substrate for Ca/CaM-PK. The other substrates for $\mathrm{Ca} / \mathrm{CaM}$-dependent phosphorylation observed in the bag cells, including the $M_{\mathrm{r}}=51,000$ protein, were similar to those observed in preparations of pooled CNS ganglia.

The finding that the bag cell phosphoprotein, BC-II, 


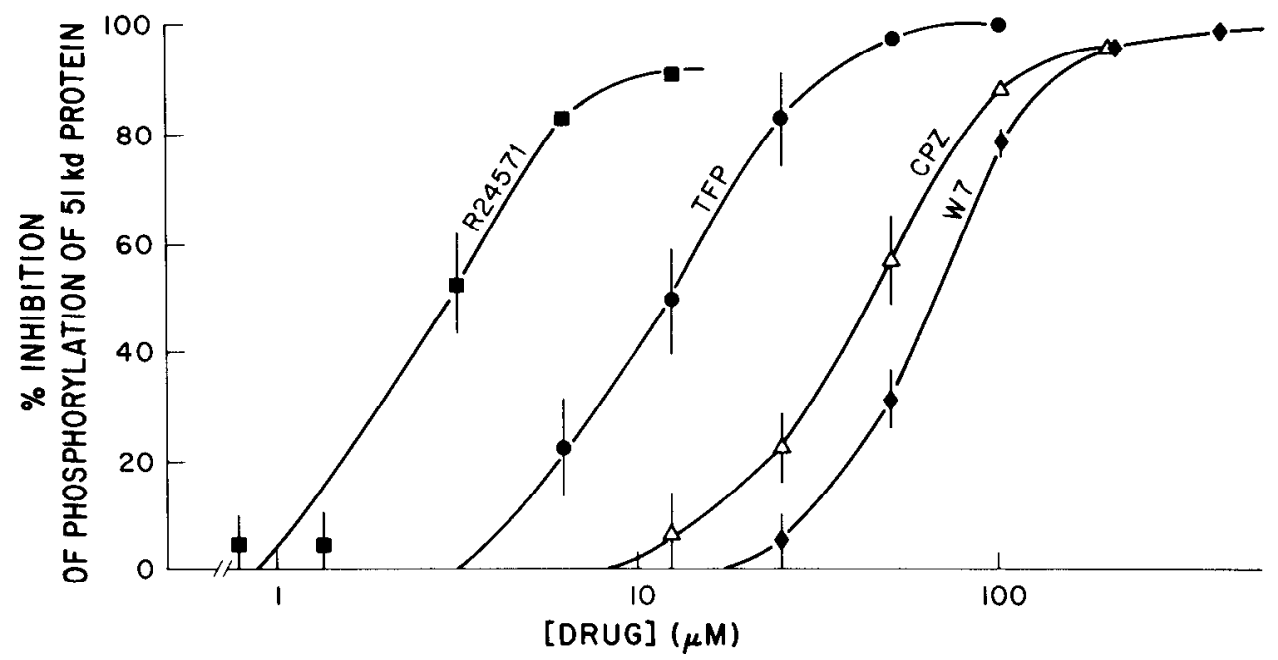

Figure 2. Inhibition by calmodulin antagonists of Ca/CaM-dependent protein phosphorylation in homogenates of $A$ plysia $\mathrm{CNS}$ ganglia. The calmodulin antagonists R24571, trifluoperazine ( $T F P$ ), chlorpromazine (CPZ), and W7 were present in the final concentrations indicated. Inhibition was quantitated by measuring phosphate incorporation into an $M_{\mathrm{r}}=51,000$ substrate in the presence of calcium $(1 \mathrm{~mm})$ plus calmodulin $(10 \mu \mathrm{g} / \mathrm{ml})$. The data represent the means and standard deviations of results from three separate experiments.

is a substrate for $\mathrm{Ca} / \mathrm{CaM}$-dependent phosphorylation is compatible with the fact that increased phosphorylation of this protein could not be observed until 20 min after the start of an afterdischarge. At this time point during the afterdischarge, cAMP levels and the phosphorylation of the cAMP-PK substrate, BC-I, have returned to control values, but there is a prominent calcium component to the bag cell action potentials (Kaczmarek et al., 1978; Jennings et al., 1982). In addition, we have observed that the phosphorylation of $\mathrm{BC}$-II can also be elevated by calcium entry induced by the ionophore, X537A (S. A. DeRiemer, P. Greengard, and L. K. Kaczmarek, unpublished observations). These results suggest that the changes observed in the phosphorylation of BC-II are due, at least in part, to the action of a $\mathrm{Ca} / \mathrm{CaM}-\mathrm{PK}$. The experiments which follow were designed to identify the $\mathrm{Ca} / \mathrm{CaM}-\mathrm{PKs}$ which are present in the Aplysia CNS and which might be involved in the regulation of $\mathrm{BC}$-II phosphorylation and bag cell activity.

Substrate specificity of $\mathrm{Ca} / \mathrm{CaM}$-PK activity. A number of $\mathrm{Ca} / \mathrm{CaM}-\mathrm{PKs}$ have been distinguished in mammalian brain, in part on the basis of their substrate specificities (Yamauchi and Fujisawa, 1980; Kennedy and Greengard, 1981; Goldenring et al., 1982, 1983; Bennett et al., 1983). Therefore, we assayed the ability of Aplysia homogenates to phosphorylate some known substrates for these enzymes (myosin light chains, tubulin, synapsin I, phosphorylase $b$, and histones) as well as substrates for cAMP-PK (casein and phosvitin) (Table I). Synapsin I was the best substrate for the $\mathrm{Ca} / \mathrm{CaM}-\mathrm{PK}$ activity in Aplysia homogenates. Lower, but significant, levels of phosphate incorporation into smooth muscle myosin light chains, histone F3, microtubule-associated proteins, and phosphorylase $b$ were also consistently observed. Little or no $\mathrm{Ca} / \mathrm{CaM}-\mathrm{PK}$-dependent phosphorylation of tubulin, phosvitin, or casein was observed in the experiment shown in Table I or in two other experiments. Skeletal muscle myosin light chains were also relatively poor substrates $(0.2 \%$ of synapsin I activity; not shown). These results suggested that the major form of calcium/ calmodulin-dependent protein kinase in Aplysia might be homologous to the mammalian synapsin I kinase known as calmodulin kinase II. Therefore, we carried out a detailed comparison of the major Aplysia kinase and mammalian calmodulin kinase II.

Comparison of Aplysia kinase with rat brain calmodulin kinase II. In the mammalian brain, synapsin I is a substrate for two $\mathrm{Ca} / \mathrm{CaM}-\mathrm{PKs}$ as well as cAMP-PK. Because the remainder of this paper consists of a comparison of the properties of the Aplysia and mammalian $\mathrm{Ca} / \mathrm{CaM}$-dependent enzymes, the following is a brief summary of the characteristics of the latter.

One-dimensional peptide mapping has shown that one of the mammalian $\mathrm{Ca} / \mathrm{CaM}-\mathrm{PK}$ s phosphorylates a serine residue recovered in an $M_{\mathrm{r}}=10,000$ proteolytic fragment of synapsin I. This Ca/CaM-PK, which is found exclusively in the cytosol, has been designated calmodulin kinase I. A second $\mathrm{Ca} / \mathrm{CaM}-\mathrm{PK}$ phosphorylates serine residues recovered in a distinct, $M_{\mathrm{r}}=30,000$, fragment. This second enzyme has been designated calmodulin kinase II and is the major synapsin I calmodulin kinase in the vertebrate CNS. This latter enzyme is found in both particulate and cytosolic fractions. Calmodulin kinase II purified from rat brain consists of three proteins (a minor doublet of $M_{\mathrm{r}}=58,000$ and 61,000, and a major protein of $\left.M_{\mathrm{r}}=50,000\right)$ that are phosphorylated in the presence of calcium plus calmodulin, bind calmodulin, and cross-react with monoclonal antibodies raised against the purified enzyme (see McGuinness et al., 1984).

In the present study, we determined the site specificity of synapsin I phosphorylation and the subcellular distribution of the synapsin I kinase activity present in homogenates of Aplysia CNS. When peptide mapping was carried out on synapsin I that had been phosphorylated by Aplysia nervous system homogenates, we observed that calcium plus calmodulin markedly stimulated the incorporation of phosphate into the $M_{\mathrm{r}}=30,000$ site, although some stimulation of incorporation into the $M_{\mathrm{r}}$ $=10,000$ site also occurred. Quantitation of the radiola- 


\section{Bag Cells}

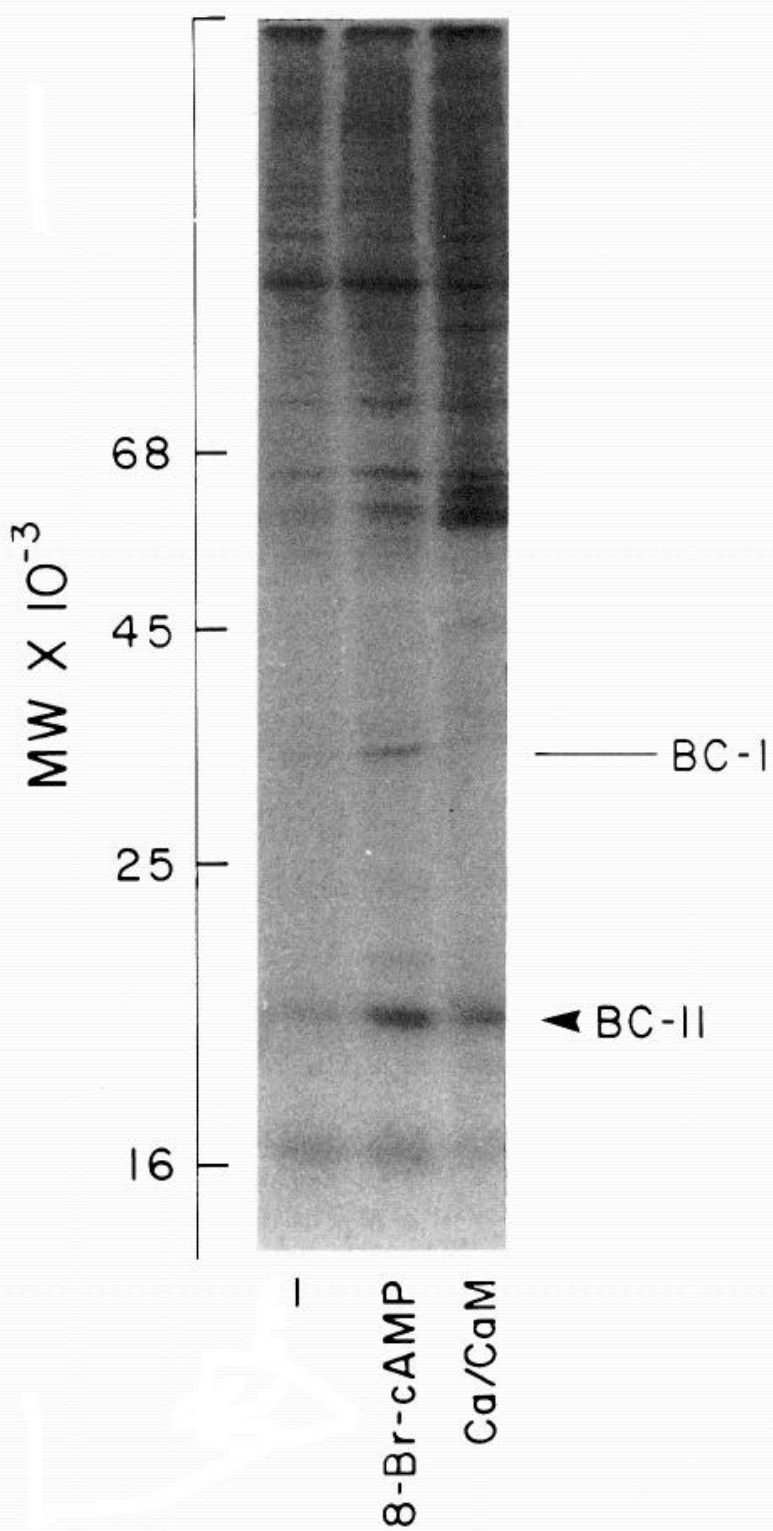

Figure 3. Phosphorylation of endogenous substrate proteins in homogenates of bag cell neurons of Aplysia in the presence of 8-Br-cAMP or calcium plus calmodulin. Phosphorylation reactions were carried out in the presence of $1.5 \mathrm{mM}$ EGTA (-), $20 \mu \mathrm{M}$ 8-Bromo-cAMP plus $1 \mathrm{mM}$ IBMX (8-Br-cAMP), or $1.0 \mathrm{~mm}$ calcium plus $10 \mu \mathrm{g} / \mathrm{ml}$ of calmodulin $(\mathrm{Ca} / \mathrm{CaM})$. Phosphorylated proteins were subjected to SDS-PAGE and autoradiography. The previously described bag cell proteins whose phosphorylation state is altered during an afterdischarge $(B C$ $I$ and $B C-I I)$ are indicated.

beled phosphate in the bands indicated that incorporation into the $M_{\mathrm{r}}=10,000$ site was only $10 \%$ of that into the $M_{\mathrm{r}}=30,000$ site (Fig. 4 ).

To determine the subcellular distribution of the synapsin I kinase activities in the Aplysia nervous system, high speed pellet and supernatant fractions were prepared. In three experiments, mean values of $79 \%$ and $21 \%$ were found for the proportions of the $\mathrm{Ca} / \mathrm{CaM}$ dependent activity recovered in the particulate pellet and cytosol, respectively. Peptide mapping revealed that nearly all $(97 \%)$ of the phosphate incorporated into synapsin I by the particulate fraction was on the $M_{\mathrm{r}}=$ 30,000 site, while the cytosolic activity phosphorylated the $M_{\mathrm{r}}=30,000$ and $M_{\mathrm{r}}=10,000$ sites to approximately the same extent ( $58 \%$ and $42 \%$, respectively).

These subcellular distributions of kinase activities paralleled those reported for synapsin I phosphorylation in

\section{TABLE I}

$\mathrm{Ca} / \mathrm{CaM}$-dependent phosphorylation of exogenous substrate proteins

Phosphorylation reactions were carried out under standard conditions, except that reaction times were $30 \mathrm{sec}$ and $5 \mu \mathrm{g}$ of Aplysia CNS ganglia homogenate were used per assay. Substrate proteins were present at a concentration of $0.2 \mathrm{mg} / \mathrm{ml}$ except for histone F3 $(0.1 \mathrm{mg} /$ $\mathrm{ml}$ ) and the microtubule-associated protein II. The latter was present as a minor constituent in the tubulin preparation used (the combined concentration of tubulin plus microtubule-associated proteins was 0.2 $\mathrm{mg} / \mathrm{ml}$ ). Because histones bind calmodulin, the calmodulin concentration in the histone assay was increased from 10 to $30 \mu \mathrm{g} / \mathrm{ml}$. Results are averages from two experiments. The specific activities of phosphorylation, using synapsin I as substrate, were 897 and $409 \mathrm{pmol} /$ $\mathrm{min} / \mathrm{mg}$ of protein in these two experiments.

\begin{tabular}{lc}
\hline \multicolumn{1}{c}{ Substrate Protein } & Relative Phosphate Incorporation \\
\hline Synapsin I & 100 \\
Smooth muscle myosin light chains & 42 \\
Histone F3 & 12 \\
Microtubule-associated protein (II) & 4 \\
Phosphorylase $b$ & 2 \\
Tubulin & 1 \\
Phosvitin & 0 \\
Casein & 0 \\
\hline
\end{tabular}

\section{SYNAPSIN I PHOSPHORYLATION}

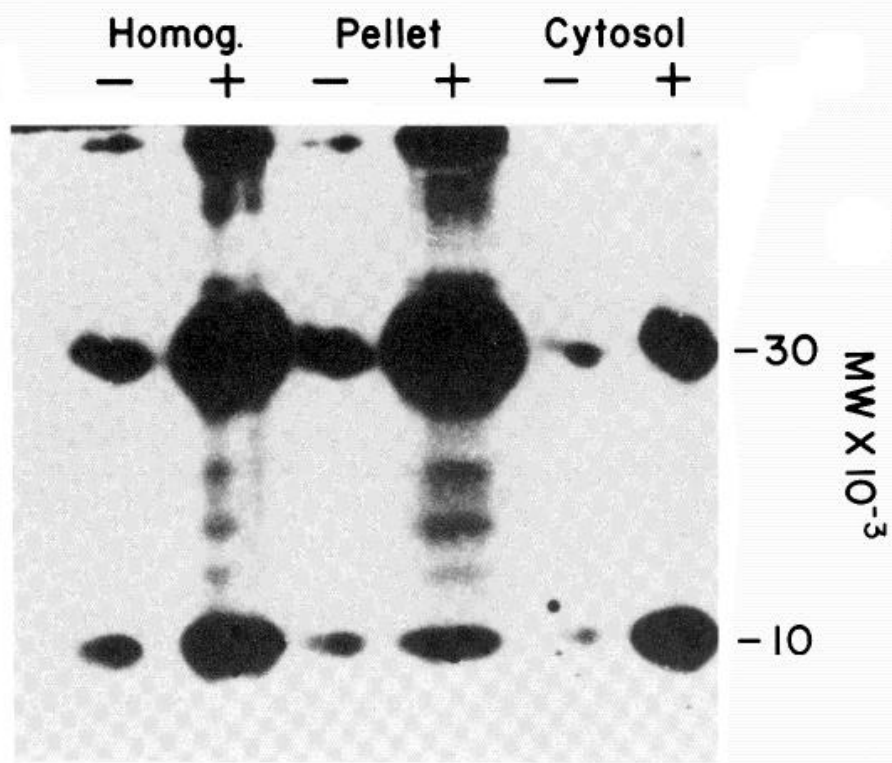

Figure 4. Phosphopeptide map of synapsin I. Synapsin I was phosphorylated by a homogenate of the Aplysia CNS (Homog.), by $100,000 \times g$ pellet $($ Pellet $)$, or by $100,000 \times g$ supernatant $($ Cytosol) in the absence $(-)$ or presence $(+)$ of calcium plus calmodulin. The phosphorylated proteins were digested by $S$. aureus protease V8 and were subjected to SDS-PAGE and autoradiography. The $M_{\mathrm{r}}=30,000$ fragment and the $M_{\mathrm{r}}=$ 10,000 fragment are indicated. Protein concentrations in the assays were synapsin $\mathrm{I}(0.1 \mathrm{mg} / \mathrm{ml})$, homogenate $(0.16 \mathrm{mg} / \mathrm{ml})$, pellet $(0.10 \mathrm{mg} / \mathrm{ml})$, and supernatant $(0.12 \mathrm{mg} / \mathrm{ml})$. 
rat brain (Kennedy et al., 1983b). They suggest that there are at least two $\mathrm{Ca} / \mathrm{CaM}-\mathrm{PKs}$ in the Aplysia CNS, one of which is present in both particulate and cytosolic compartments and the other of which is primarily cytosolic, and that the major $\mathrm{Ca} / \mathrm{CaM}-\mathrm{PK}$ in the Aplysia

\section{IMMUNOBLOT}

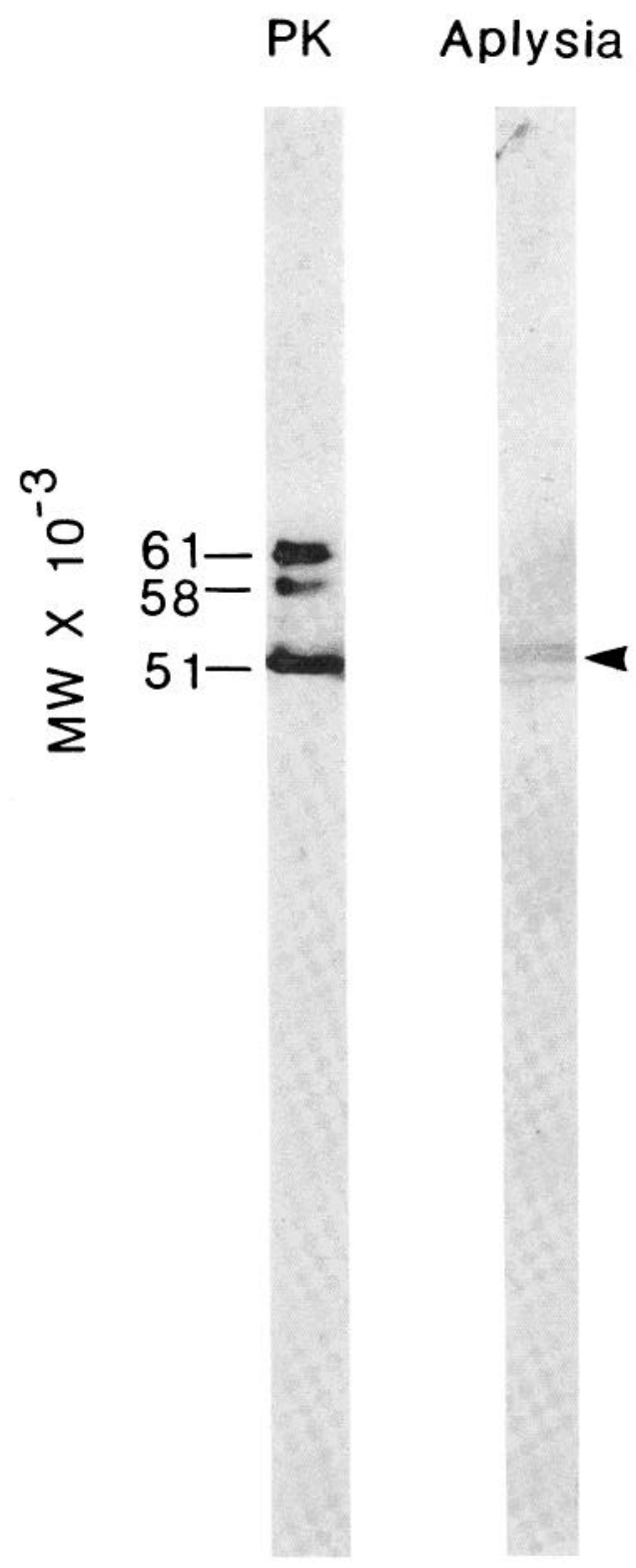

Figure 5. Immunoblot illustrating cross-reactivity of $M_{\mathrm{r}}=$ 51,000 protein from Aplysia CNS ganglia with a monoclonal antibody to mammalian calmodulin kinase II. Purified calmodulin kinase II $(P K ; 0.5 \mu \mathrm{g})$ and Aplysia CNS ganglia particulate fraction (Aplysia; $100 \mu \mathrm{g}$ ) were transferred to nitrocellulose paper after separation of proteins by SDS-PAGE. The transfers were incubated with monoclonal antibody (C42.1) which was raised against purified calmodulin kinase II, followed by alkaline phosphatase-conjugated incubation with goat anti-mouse IgG $\left(\mathrm{Fab}^{\prime}\right)^{2}$ fragment and staining for alkaline phosphatase activity as described (Kelly et al., 1984). Immunoreactive proteins were visualized by autoradiography and are indicated by lines for PK and an arrowhead for Aplysia.

\section{$51 \mathrm{kd}$ PHOSPHOPEPTIDE MAP}

PK

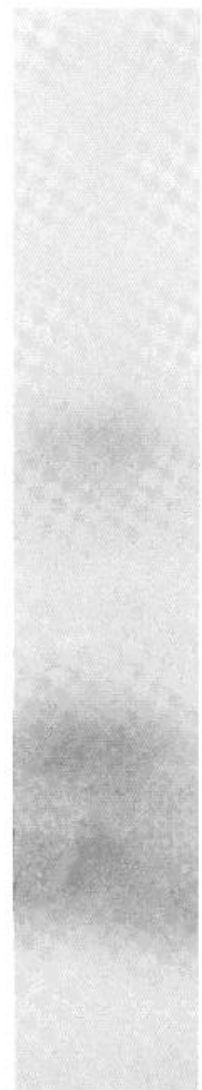

Aplysia

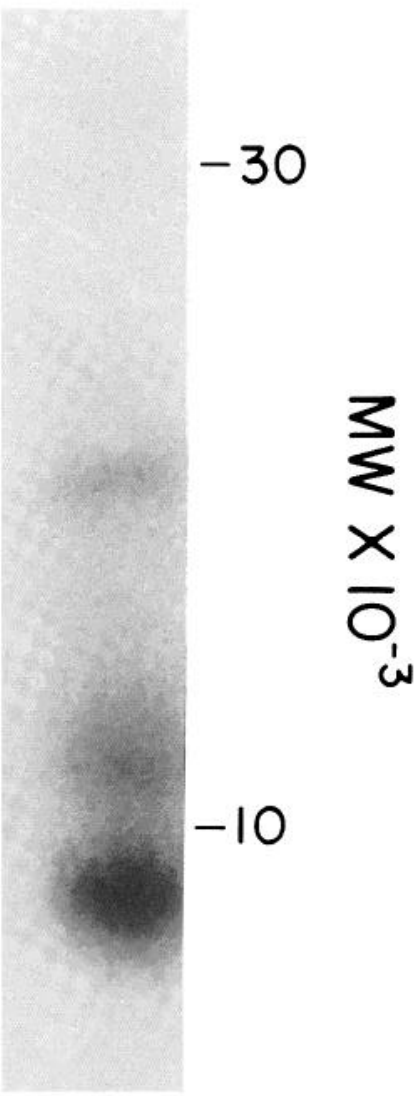

Figure 6. Phosphopeptide map of $M_{\mathrm{r}}=51,000$ substrates for $\mathrm{Ca} / \mathrm{CaM}-\mathrm{PK}$ found in Aplysia CNS ganglia homogenate (Aplysia) and in purified mammalian calmodulin kinase II $(P K)$. The $M_{\mathrm{r}}=51,000$ substrates in the two preparations were subjected to endogenous phosphorylation, separation by SDSPAGE, one-dimensional peptide mapping, and autoradiography.

nervous system is similar to mammalian calmodulin kinase II.

Comparison of $M_{r}=50,000$ to 51,000 phosphoproteins from rat and Aplysia. To compare further the major Aplysia kinase and rat calmodulin kinase II, we tested the ability of monoclonal antibodies to calmodulin kinase II to recognize proteins in the Aplysia nervous system. The major immunoreactive protein $\left(M_{\mathrm{r}}=51,000\right)$ in a particulate fraction of Aplysia CNS migrated in the region of the immunoreactive $M_{\mathrm{r}}=50,000$ to 51,000 phosphoprotein subunit of purified calmodulin kinase II (Fig. 5). Some preparations of Aplysia showed heterogeneity in this region (e.g., Fig. 5), whereas others, showed a single band. This suggested that the prominent $M_{\mathrm{r}}=$ 51,000 substrate for $\mathrm{Ca} / \mathrm{CaM}$-dependent phosphorylation in Aplysia might also be a component of an endogenous calmodulin kinase II.

The rat and Aplysia $M_{\mathrm{r}}=50,000$ to 51,000 phospho- 


\section{CaM BINDING}

\section{PK Aplysia}

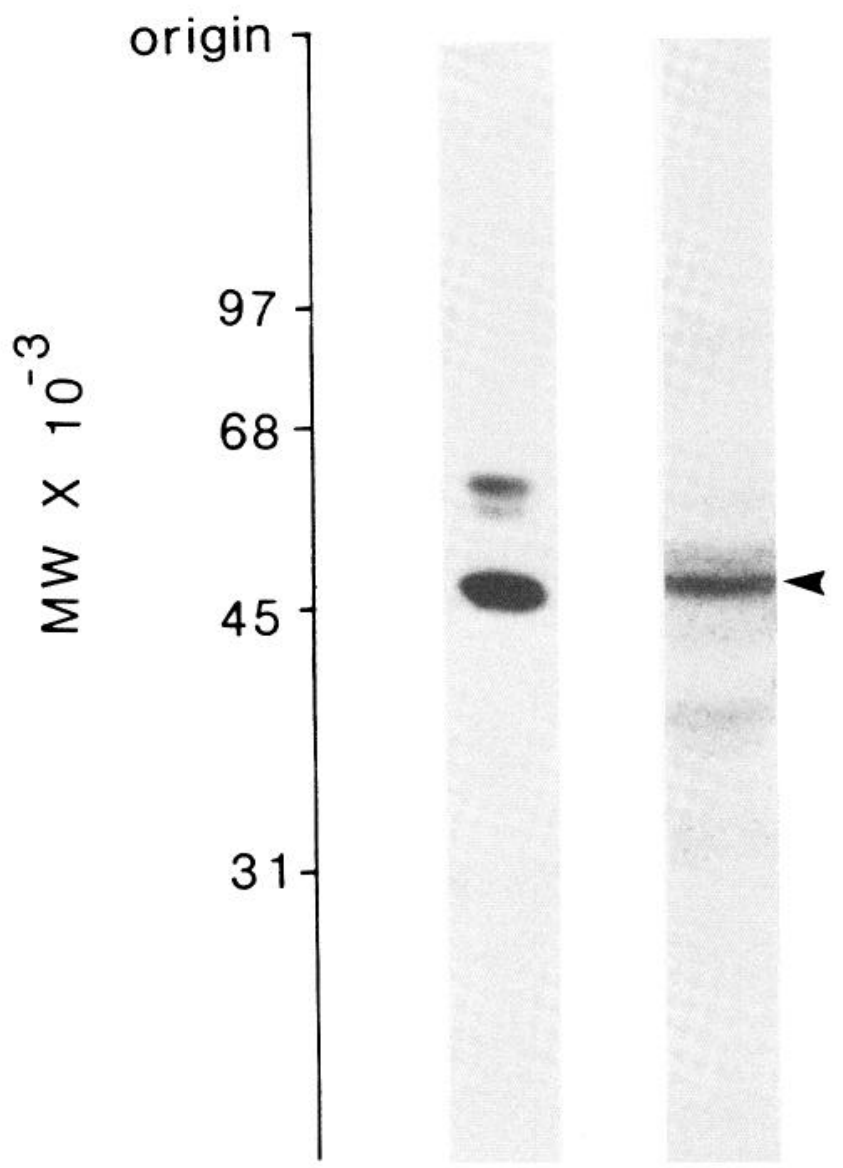

Figure 7. Calmodulin-binding proteins in homogenate of Aplysia CNS ganglia and purified mammalian $\mathrm{Ca} / \mathrm{CaM}-\mathrm{PK}$ II. Samples of Aplysia CNS ganglia homogenate (100 $\mu \mathrm{g} ;$ Aplysia) and calmodulin kinase II $(3 \mu \mathrm{g} ; P K)$ were subjected to SDSPAGE. $\left[{ }^{125} \mathrm{I}\right]$ Calmodulin binding was performed by the method of Carlin et al. (1981) in the presence of calcium. The arrowhead indicates the $M_{\mathrm{r}}=51,000\left[{ }^{125} \mathrm{I}\right]$ calmodulin-binding protein in Aplysia.

rylated proteins had similar mobilities on one-dimensional SDS-polyacrylamide gels. When the bands corresponding to these phosphoproteins were cut out of one SDS gel and subjected to partial proteolytic digestion with $S$. aureus V8 protease on a second SDS gel, the phosphopeptide fragments produced from the rat and Aplysia proteins had similar molecular weights (Fig. 6).

We also looked for calmodulin-binding proteins which might be subunits of the major Aplysia calmodulin kinase. When $\left.{ }^{125} \mathrm{I}\right]$ calmodulin binding to Aplysia nervous system proteins separated by SDS-PAGE was assayed, a major calmodulin-binding protein migrated in the region of the $M_{\mathrm{r}}=50,000$ to 51,000 calmodulin-binding protein in purified calmodulin kinase II (Fig. 7).

The similarity of the rat and Aplysia $M_{\mathrm{r}}=50,000$ to 51,000 proteins in their antigenicity, ability to bind calmodulin, and phosphopeptide patterns upon partial pro- teolysis further supports the hypothesis that the major form of $\mathrm{Ca} / \mathrm{CaM}-\mathrm{PK}$ activity in Aplysia nervous system homogenates is homologous to mammalian calmodulin kinase II.

The identification of calmodulin kinase II in the Aplysia nervous system raises the question of the function(s) this enzyme has within this invertebrate nervous system. Evidence collected in studies of the vertebrate CNS suggests both pre- and postsynaptic roles for this enzyme in neurotransmission (see McGuinness et al., 1984). The calcium-dependent processes in the bag cells which involve BC-II and calmodulin kinase II may include modifications either in (1) membrane properties during the afterdischarge, (2) the onset of the subsequent refractory period, or (3) neurosecretion. Injection of calmodulin kinase II purified from rat into Aplysia neurons, such as the bag cells, is one way to address this question.

\section{References}

Acosta-Urquidi, J., J. T. Neary, and D. L. Alkon (1982) $\mathrm{Ca}^{2+}$. dependent protein kinase regulation of $\mathrm{K}^{+}(\mathrm{V})$-currents: A possible biochemical step in associative learning of Hermissenda. Soc. Neurosci. Abstr. 8: 825.

Adams, W. B., and I. B. Levitan (1982) Intracellular injection of protein kinase inhibitor blocks the serotonin-induced increase in $\mathrm{K}^{+}$conductance in Aplysia neuron R15. Proc. Natl. Acad. Sci. U. S. A. 79: 3877-3880.

Alkon, D. L., J. Acosta-Urquidi, J. Olds, G. Kuzma, and J. T. Neary (1983) Protein kinase injection reduces voltage-dependent potassium currents. Science 219: 303-305.

Bennett, M. K., N. E. Erondu, and M. B. Kennedy (1983) Purification and characterization of a calmodulin-dependent protein kinase that is highly concentrated in brain. J. Biol. Chem. 258: 12735-12744.

Carlin, R. K., D. J. Grab, and P. Siekevitz (1981) Function of calmodulin in postsynaptic densities. III. Calmodulin-binding proteins of the postsynaptic density. J. Cell Biol. 89: 449455.

Castellucci, V. F., E. R. Kandel, J. H. Schwartz, F. D. Wilson, A. C. Nairn, and P. Greengard (1980) Intracellular injection of the catalytic subunit of cyclic AMP-dependent protein kinase simulates facilitation of transmitter release underlying behavioral sensitization in Aplysia. Proc. Natl. Acad. Sci. U. S. A. 77: 7492-7496.

Cleveland, D. W., S. G. Fischer, M. W. Kirschner, and U. K. Laemmli (1977) Peptide mapping by limited proteolysis in sodium dodecyl sulfate and analysis by gel electrophoresis. J. Biol. Chem. 252: 1102-1106.

DeLorenzo, R. J., S. D. Freedman, W. B. Yohe, and S. C. Maurer (1979) Stimulation of $\mathrm{Ca}^{2+}$-dependent neurotransmitter release and presynaptic nerve terminal protein phosphorylation by calmodulin and a calmodulin-like protein isolated from synaptic vesicles. Proc. Natl. Acad. Sci. U. S. A. $76: 1838-1842$.

DeRiemer, S. A., L. K. Kaczmarek, and P. Greengard (1982) Calcium-calmodulin dependent protein phosphorylation in Aplysia neurons. Soc. Neurosci. Abstr. 8: 565.

Glynn, I. M., and J. B. Chappell (1964) A simple method for the preparation of ${ }^{32} \mathrm{P}$-labelled adenosine triphosphate of high specific activity. Biochem. J. 90: 147-149.

Goldenring, J. R., B. Gonzalez, and R. J. DeLorenzo (1982) Isolation of brain $\mathrm{Ca}^{2+}$-calmodulin tubulin kinase containing calmodulin binding proteins. Biochem. Biophys. Res. Commun. 108: 421-428.

Goldenring, J. R., B. Gonzalez, J. S. McGuire, Jr., and R. J. DeLorenzo (1983) Purification and characterization of a calmodulin-dependent kinase from rat brain cytosol able to phosphorylate tubulin and microtubule-associated proteins. 
J. Biol. Chem. 258: 12632-12640.

Grab, D. J., R. K. Carlin, and P. Siekevitz (1981) Function of calmodulin in post-synaptic densities. II. Presence of a calmodulin-activatable protein kinase activity. J. Cell Biol. 89: $440-448$.

Grand, R. J. A., S. V. Perry, and R. A. Weeks (1979) Troponin C-like proteins (calmodulins) from mammalian smooth muscle and other tissues. Biochem. J. 177: 521-529.

Hidaka, H., M. Asano, S. Iwadare, I. L. Matsumoto, T. Totsuka, and N. Aoki (1978) A novel vascular relaxing agent, $N$-(6aminohexyl)-5-chloro-1-naphthalene sulfonamide, which affects vascular smooth muscle actomyosin. J. Pharmacol. Exp. Ther. 207: 8-15.

Jennings, K. R., L. K. Kaczmarek, R. M. Hewick, W. J. Dreyer, and F. Strumwasser (1982) Protein phosphorylation during afterdischarge in peptidergic neurons of Aplysia. J. Neurosci. 2: $158-168$.

Kaczmarek, L. K., and J. A. Kauer (1983) Calcium entry causes a prolonged refractory period in peptidergic neurons of Aplysia. J. Neurosci. 3: 2230-2239.

Kaczmarek, L. K., K. Jennings, and F. Strumwasser (1978) Neurotransmitter modulation, phosphodiesterase inhibitor effects and cAMP correlates of afterdischarge in peptidergic neurites. Proc. Natl. Acad. Sci. U. S. A. 75: 5200-5204.

Kaczmarek, L. K., K. R. Jennings, F. Strumwasser, A. C. Nairn, U. Walter, F. D. Wilson, and.P. Greengard (1980) Microinjection of catalytic subunit of cyclic AMP-dependent protein kinase enhances calcium action potentials of bag cell neurons in cell culture. Proc. Natl. Acad. Sci. U. S. A. 77: 7487-7491.

Kaczmarek, L. K., K. R. Jennings, and F. Strumwasser (1982) An early sodium and a late calcium phase in the afterdischarge of peptide-secreting neurons of Aplysia. Brain Res. 238: 105-115.

Kandel, E. R., and J. H. Schwartz (1982) Molecular biology of learning: Modulation of transmitter release. Science 218: 433-443.

Kelly, P. T., T. L. McGuinness, and P. Greengard (1984) Evidence that the major postsynaptic density protein is a component of a $\mathrm{Ca}^{2+}$-/calmodulin-dependent protein kinase. Proc. Natl. Acad. Sci. U. S. A. 81: 945-949.

Kennedy, M. B., and P. Greengard (1981) Two calcium/calmodulin-dependent protein kinases, which are highly concentrated in brain, phosphorylate protein I at distinct sites. Proc. Natl. Acad. Sci. U. S. A. 78: 1293-1297.

Kennedy, M. B., M. K. Bennett, and N. E. Erondu (1983a) Biochemical and immunochemical evidence that the "major postsynaptic density protein" is a subunit of a calmodulindependent protein kinase. Proc. Natl. Acad. Sci. U. S. A. 80: 7357-7361.
Kennedy, M. B., T. L. McGuinness, and P. Greengard (1983b) A calcium/calnodulin-dependent protein kinase from mammalian brain that phosphorylates synapsin I: Partial purification and characterization. J. Neurosci. 3: 818-831.

Laemmli, U. K. (1970) Cleavage of structural proteins during the assembly of the head of bacteriophage T4. Nature 277: $680-685$.

Lowry, O. H., N. J. Rosebrough, A. G. Farr, and R. J. Randall (1951) Protein measurement with Folin phenol reagent. J. Biol. Chem. 193: 265-269.

McGuinness, T. L., Y. Lai, C. C. Ouimet, and P. Greengard (1984) Calcium/calmodulin-dependent protein phosphorylation in the nervous system. In Metabolic and Functional Aspects of Calcium, I, Plenum Press, New York, in press.

Novak-Hofer, I., and I. B. Levitan (1983) $\mathrm{Ca}^{++} /$calmodulinregulated protein phosphorylation in the Aplysia nervous system. J. Neurosci. 3: 473481.

Palfrey, H. C., J. E. Rothlein, and P. Greengard (1983) Calmodulin-dependent protein kinase and associated substrates in Torpedo electric organ. J. Biol. Chem. 258: 9496-9503.

Schulman, H., and P. Greengard (1978) $\mathrm{Ca}^{2+}$-dependent protein phosphorylation system in membranes from various tissues, and its activation by "calcium-dependent regulator." Proc. Natl. Acad. Sci. U. S. A. 75: 5432-5436.

Stuart, D. K., A. Y. Chiu, and F. Strumwasser (1980) Neurosecretion of egg-laying hormone and other peptides from electrically active bag cell neurons of Aplysia. J. Neurophysiol. 43: 488-498.

Towbin, H., T. Staehelin, and J. Gordon (1979) Electrophoretic transfer of proteins from polyacrylamide gels to nitrocellulose sheets: Procedure and some applications. Proc. Natl. Acad. Sci. U. S. A. 76: $4350-4354$.

Ueda, T., and P. Greengard (1977) Adenosine $3^{\prime}: 5^{\prime}$-monophosphate-regulated phosphoprotein system of neuronal membranes. I. Solubilization, purification, and some properties of an endogenous phosphoprotein. J. Biol. Chem. 252: 51555163.

Van Belle, H. (1981) R 24571 : A potent inhibitor of calmodulinactivated enzymes. Cell Calcium 2: 483-494.

Weiss, B., W. Prozialeck, M. Cimino, M. S. Barnette, and T. L. Wallace (1980) Pharmacological regulation of calmodulin. Ann. N. Y. Acad. Sci. 356: 319-345.

Yamauchi, T., and H. Fujisawa (1979) Most of the $\mathrm{Ca}^{2+}$ dependent endogenous phosphorylation of rat brain cytosol proteins requires $\mathrm{Ca}^{2+}$-dependent regulator protein. Biochem. Biophys. Res. Commun. 90: 1172-1178.

Yamauchi, T., and H. Fujisawa (1980) Evidence for three distinct forms of calmodulin-dependent protein kinases from rat brain. FEBS Lett. 116: 141-144. 